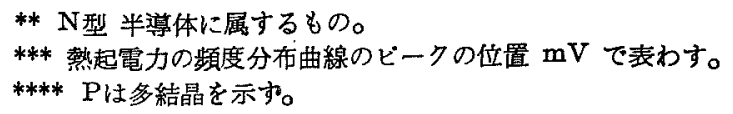

これ等の欠宿や結合内容の相蓬が生成温度に直接対応するという稂肳が今日の所未だ不 十分であるから，鉱物の諸物性の偏倚を支配する物理化学的本性を追求すると共に，それ 等の物理化学的本性と生成環境との関係を規定するために今後より多くの実験とデータ 一の集皘が必要となつてくるであろう。

附記 Fisher は上記目的のため，黄鉄鉱の顕微鏡的研究，分光分析，X線分析，示差 熱分析，加熱実臨等を行つて熱起電力を支配する本賢を追求しているが，他硫化鉣物徽粒 子の存在と微量成分が影響している程度で他の性質との関係は見出されなかつた事を報 告している。

\title{
北部北上山地岩泉附近の接觸変成岩類（II）
}

On the contact-metamorphic rocks from Iwaizumi, northern Kitakami mountainlands (II)

$$
\text { 加 納 専 (Hiroshi Kano)* }
$$

\section{(3) 石灰岩の内部及び緑辺部にみられる变成岩類}

変成带内带に分布する石灰岩鹰の大部分は単純な晶質石死岩に過ぎいが，その中に介 在する包有岩塊や上下盤の異質岩層との漸移部には秏々の石灰珪酸塩鉣物から成る興味 ある鉱物組合せが発㯇している。

石灰岩中の珄質包有岩から導かれた变成岩類 本地域の石存岩層はとくにその上下盤 近くに多くの珪婜包有岩塊を有することを前に述へたたこれらの包有岩塊中には、一般に 透角閃石または迻輝石を生じている。

i) 迹解石 $\cdot$ 方解石 $\cdot$ 石英岩

下部石灰岩啳のほほ中央部に多数含まれる珪質包有岩塊の一で，石英・方解石のほか比 較的多量の透角閃石 $\left(2 \mathrm{~V}(-) 88^{\circ}\right)$ のポイキロブラスチック斑状变晶を含んでいる。

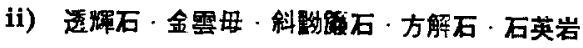

小本川屈曲部の下部石欧岩層下盤より約 $100 \mathrm{~m}$ 上位に産す。石英・方解石のモサイク 状石基中に透輝石・金雲母および斜䝮穊石 $\left(2 \mathrm{~V}(+) 70^{\circ}\right)$ を生じている。

* 秋田大学鉣山学部鉱山地質学教室.

1）同様の鉱物組合せは，沢中沢接螌部より約 $1200 \mathrm{~m}$ 唯れた上部石灰岩層の上盤に

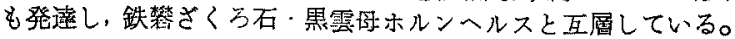


西灰岩との間に掋散反応黄を有する泥 質または泥交蜇包有岩から導かれた变成 岩類 潼ノ沢接触部加ら約 $50 \mathrm{~m}$ 離れた下 部石灰岩層の下盤の汁質または泥灰䝷夾 みを有する部分に種々の興味ある变成現 像が観祭された。次にその2 例を記す。

例1. 夾みの中心部は黒雲母-灰曹長 石1)(An26)・石英の組合せであるが，石 扊岩に接する周縁部に向つてつぎのよう な想則的な鎹物㚆化が認められる(第 9 図 2，3，4)。

（1）黑雲母が減少し角閃石し透輝石 が上の鉱物組合せに入つてくる。この場

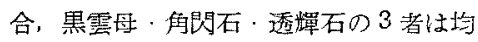
一に湿りあつて其䒚するのていなく，透 輝石一角閃石，角閃石一黒零母るいは 透輝石一黒雲持のそれそれの組合せが交 互に縞状配列をなす傾问がある。この部 分の斜長石は中心部上りやや兏長石分を 增し酸性中性長石 (An 32-35) と交る。 なお少舅の梮石を生している(第9图2)。

(2) 石或岩との境界近くでは黒雲度 は全く消失し, 角闒石 - 透輝石・石英
第 8 图 珪線石(S) と紅杜石 (A)の 種々の産状
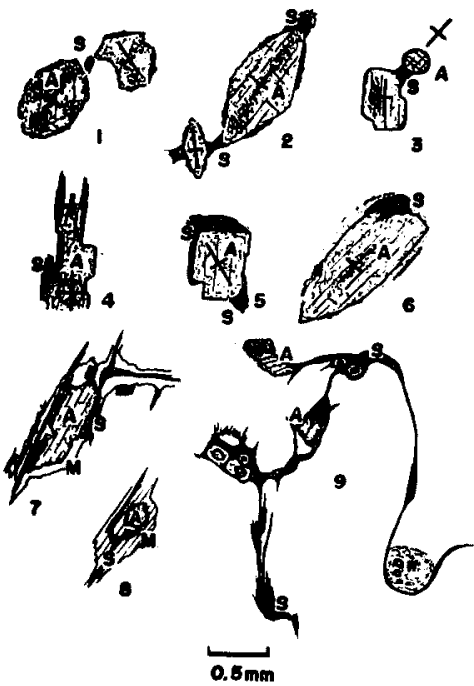

（1６. ホルンヘルス，7-9．湆）橋花菵 閃緑岩， $\mathrm{M}$ ：白雲度， $m$ ：モンモリロン石 様鉝物)

斜長石の組合せとなり，少量つ方解石も入つてくる。解石には，透辉石と安定に共存す るようにみえる淡緑色焦閃石 $\left(2 \mathrm{~V}=(-) 70^{\circ} \pm\right)$ と，透輝石を包みこれを交代しつつある

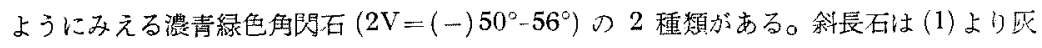
長石分に富化i，An 37 となる(符 9 图 3)。

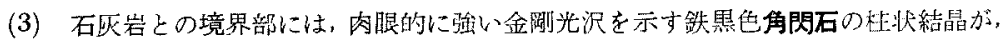
乳白色真珠光沢の斜長石およぴ石英・方解石とこもにプール状に発達することがある。

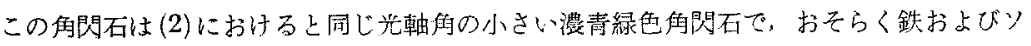

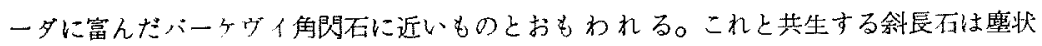
包有物で活濁した灰曹長石 (An 25-30) で，部分的にカリ長石化している。なおこの部

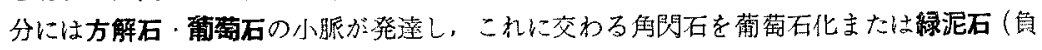
ペンニン) 化している。要するにこのような異常变成部は石灰岩と包有岩塊の境界面に沿 つて，アルカリ（とくにソーダ）と鉄が比較的濃集した部分と考えられる(符 9 図 4)。

(4) 石灰岩側は大部分方解石から成るが，境界部近くには透輝石と若干の角閃石を生 じている。境界部から遠ざかると角閃石は消え，透輝石も少なくなる。

例 2. (第 9 园 5) 前例の産出地点から $50 \mathrm{~cm}$ しか嚾れていないが，再結鼠度は

1) 中核部 An 22，外殸部 An 27 の逆累帶をなすものもある。 
第 9 図

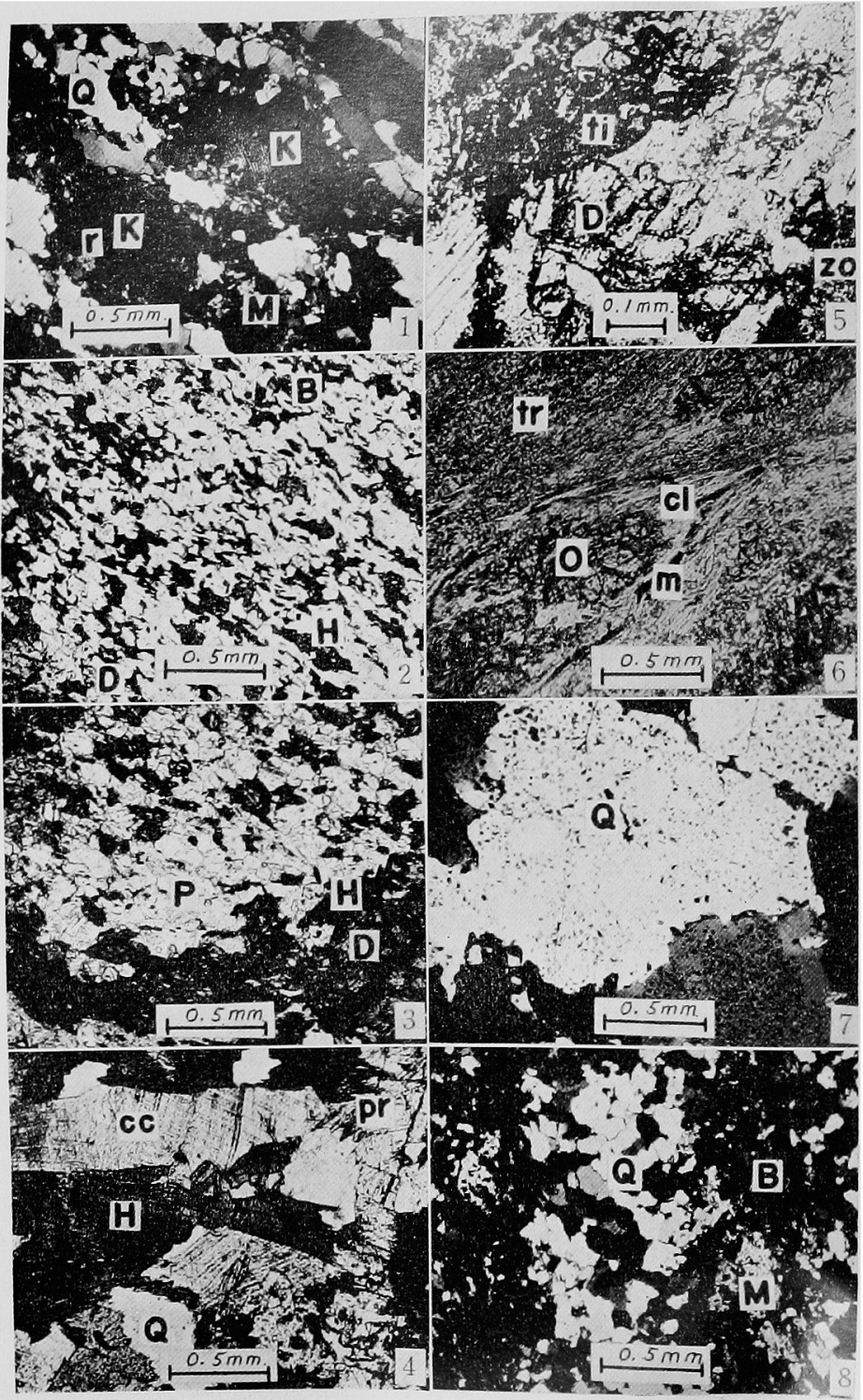

1. 砂崖起源ホルンヘルス（内ノ沢）。中央の暗黒に近い 2 つの眼球状斑晶はカリ長 石 $(\mathbf{k})$ 。そのまわりはミルメカイト $(\mathrm{r})$ を有する灰曹長石の微毘で縁取られている。 
はるかに低い。包有岩塊の中心部は透角閃石・黑里曲・石英（それに少量の方解石・斜長 石および透輝石) の組合せから成る細粒ホルンヘルスであるが，周縁部に狭い应散反応带

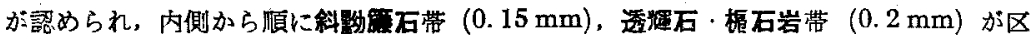
別され，石灭岩部に直接する最外側を磁鉄鉱带 $(0.07 \mathrm{~mm})$ がとりまいている。これら の特銜鉣物のほかに緑泥石・葡萄石および方解石も部分的に発達する。本例によく似た metamorphic diffusion は鈴木醇1)により，日高带南部のホルンールス中の幾成石灰 質団塊加報告された。

以上の 2 例に示した石灰岩に夾まれた包有岩塊の中心部と周辺部における铉物変化は。 いずれも石灰岩と包有岩塊との間に行われた成分移動を伴なう変成分化作用の結果を示 すものとおもわれる。この場合，Ca が石灭岩から包有岩側に移動すると同時に，おそら

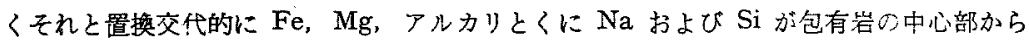

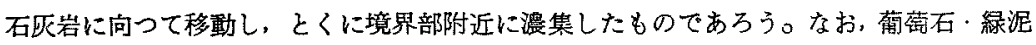

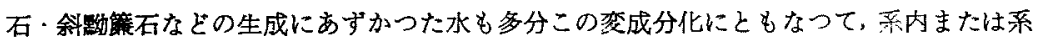
外加境界部に導入された。

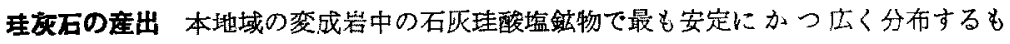

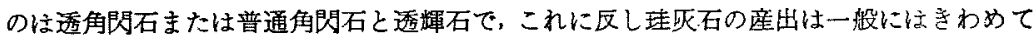
限定され量もいちじるしく少ないことは注目に值する。珪可石の産出が比较的稀な理由 は，一には石瓜岩の庄大な分布にもかかわらず，花崗岩体が直接石灰岩を切ることがほと んどないことによるものである。

珪灰石が花崗岩と石灰岩の接蛙部に生じている唯一の例が小本川の逆 $\mathrm{S}$ 字状屈出部で 見出されている。ここでは乙茂型花岗閃緑岩の小迸入岩脈の一であるべグマタイトが下 部石区岩の一部を切り，その接触部に種々のスカルン铉物を生している。ここに発達する

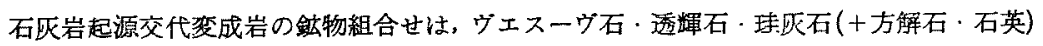
の組合せとサーラ輝石・中性是石 (An 32) . 石英の組合せの 2 種で, 前者は Goldschmidt の Class 10，後者はClass 7 にそれぞれ相当する。たたしこの場合にも珪灰

1）铪木醇：地質， 41，666-680， 1934.

\section{第 9 圆説明(つつきき)}

2. 石灰岩に夾まれた泥灰躓岩起源ホルンヘルスの比較的中心に近い部分（滰ノ沢）。 黒雲母 $(\mathrm{B})$ ，普通角閃石 $(\mathrm{H})$ ，透輝石 (D) および斜長石加方成る。(開放二コル)

3. 同上。周緑部, 透辉石 $(\mathrm{D})$ のまわりを蓇青緑色普通角閃石 $(\mathrm{H})$ が包んで発逹 するもの。(開放ニコル)

4. 同 上。境界部の濃青緑色角閃石 $(\mathrm{H})$, 方解石 $(\mathrm{cc})$ ，兏曹長石 $(\mathrm{P})$, 石英 $(\mathrm{Q})$ 抒 よびそれらを貴めく葡萄石（pr）眽。(開故ニコル)

5. 㧓散反応营を有する泥灭質岩起源ホルンヘルス（滰ノ沢）。cc：石灰岩部，m：

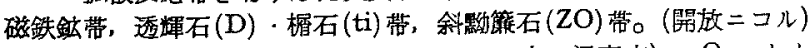

6. 汃んらん岩起源片状ホルンヘルス (内ノ沢東方)。 $\mathrm{O}$ ：汃んん石， $\mathrm{Cl}$ ：緑泥 石, tr : 透角嗿石, $\mathrm{m}$ : 磁鉄鉱。(開放ニコル)

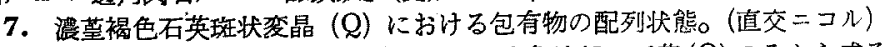

8. 縞状片麻岩に似た岩石 (褧野)。ただし白色縞部は石英 $(Q)$ のみから成る。（直交二 コル) 
石の座出はぺグマタイト接触点からせいぜい $10 \mathrm{~m}$ 以内にすぎない゙。

（4）超塩基性火成岩から埒かれた变成岩一透角閶石・粶泥石・かんらん石片状ホルン ヘルス (第 9 図 6)

内ノ沢附近の一小沢に産する。層位的には下部石灰岩の下位，花嵛岩体加ら約 $50 \mathrm{~m}$

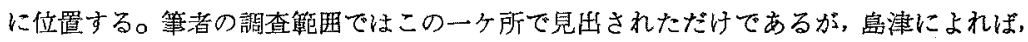

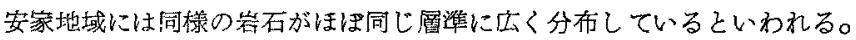

鏡下では残留珽状片状棈造の頭著な岩石で，汃んらん石(おそらく残留斑晶)・緑泥石・

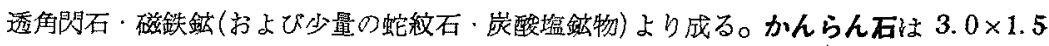
$\mathrm{mm}$ の眼球状斑状残晶で，桯微の破砕粒状化作用を受け，数個の小結晶が集合して一珽 晶をつくること肪多い。 $2 \mathrm{~V}= \pm 90^{\circ}$ で普通のかんらん岩中のものと同様の成分と方もわ れる。周縁㧍よび割目に沿つて緑泥石または透角閔石に交代されている。緑泥石による 置換が進んだものでは，緑泥石化した元のかんらん石の中央部を包みかずかにかんらん石 の外款が夾状に残つている。この種の緑泥石は底面䢃開の発遵した比較的大型の板状結

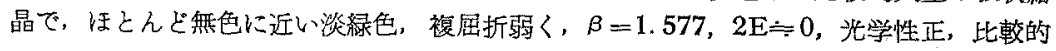
アメサイト分子に富んだ苦土緑泥石 (正ペンニン)の一種と考えられる。透角閃石は無色， $\mathrm{c} \wedge Z=18^{\circ}, 2 \mathrm{~V}=(--) 76^{\circ}, \alpha=1.622, \gamma=1.645, \gamma-\alpha=0.023$, 若干の鉄を含ん㘿陽 起石㗨透角閃石と考えられる。

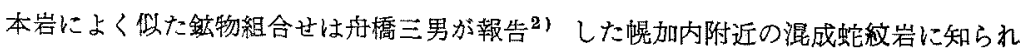
ている。

\section{7. 乙茂型花崗閃緑岩周辺の変成岩類}

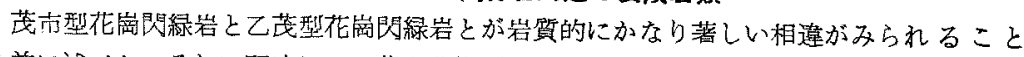
を前に述へた。それに関連して乙茂型花崗閃緑岩に淔接する地域に発達する変成岩類が， 次に述べるょうな点で, 茂市型花崗眨緑岩に值接する地域（内ノ沢以西）のそれとかなり 本質的に異なることが注目される。

i) 茂市型地域には狭い範眮ながら縞状片麻岩带 (白雲母亜带)が発達する。ここでは 紅柱石，珪線石は白雲母化作用を受けて不安定となり，それに代つてコランダムが 安定

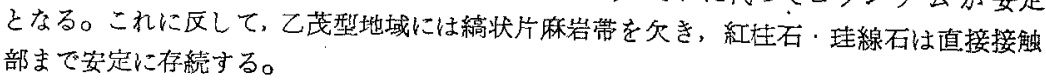

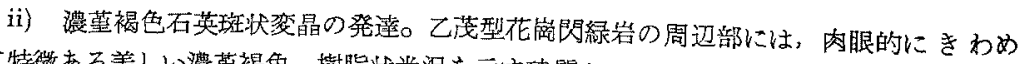

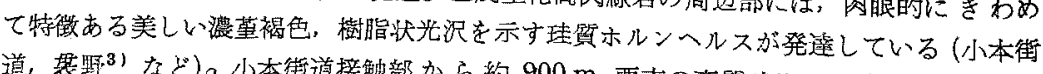

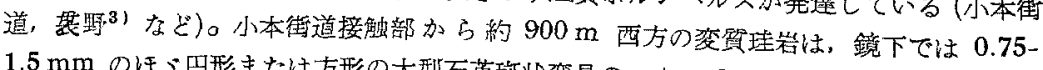
$1.5 \mathrm{~mm}$ のほ・円形まお江方形の大型石英斑状変晶の sutured aggregate と，それらの間 を夼填する細加石英変晶・累雲母おるて白雲母より成る。石英の大型斑状変晶中には 累雲母・ざくろ石・斜長石・電気石・珪線石などの丸味を带びた無数の包有物が含まれ， 第9図7のような環鎖状配列をなすことが多い。この場合環の中心部は包有物文如し，

1) なお゙ヘグマタイト自身の内部にも興味ある同化混成現象が認められるが、これにつ

2）撟三男：地筫，51，119-131，1944.

3) 乙茂型花厥閃緑岩体東縁の接触部。 
また同一湤状変晶中に数個の環が存在することも稀ではない。

この種の石英斑状変晶は岩生周一1) が楖井地方の領家変成岩で注目したものと全く同 様のもので、岩生はこれを花崗岩化作用の過程に於ける增進的な再結晶作用によるものと 解釈した。段戸およで笠置地方の領家变成带にも同様の変賀珪岩が知られているが，小出2ね およぴ有田 ${ }^{3)}$ は新期花崗閃緑岩による複変成現象として説明した。筆者はここでは後者 の解积にしたがい，新期花崗閃緑岩（乙茂型）の迸入に関連した複変成的な再結晶作用に よつて生成したものと考える。

これと同様の石英斑状変晶が injection vein 状に発達して一見すると縞状片麻岩に似 た岩石（第 9 図 8)を作ることも接触部近くにはしばしばある（小本街道，下猿沢，翌野 なと゚り。このような岩石では一般に白雲母は比較的少なく，紅杜石や珪線石が安定に存続 する。

iv) Orijärvi 型堇青石岩の発澾. 乙茂型花崗閃緑岩の東側の変成帯には，田老鉱山 の鈳硫化鉄鉣床を含む剪裂带に伴なつて多量の堇青石を有する塩基性火山岩 起源の交代 変成岩が諸所に発達している4!これは俈青石と黒雲母の組合せから成るものであるが， 斜方角閃石およびカミングトン角閃石を含む斜長石角閃岩としばしば密接な共存関保 を示している。この種の前裂带ならびに交代变成岩類は岩泉・安家地域の変成芇には決 して見られない。

以上のように，関連花崗岩の型式が異なるにしたがつて，変成賞における鉣物組合せお よび安定関係に著しい差避を生ずることは興味ある事実である。同じよっうなことは小 出”により段戸地方で明らかにされており，清崎花崗閃緑岩に関連した古期変成带々三都 橋花萹閃緑岩に関連した新期変成带とはいろいろの点で対蹠的な相異を示している。

\section{8. 变成根ならびに変成条件}

さきに筆者は4)本地域の接触変成岩類が領家变成带のそれに比較的よく類似している ことを強調したがてての主な根拠を上に迅べた記载から要約すれば次のようである。

(1) 紅杜石または線石と黒雲昌ならびにカリ長石との安定な共存。

(2) 䋹状片麻岩带の存在。

(3) 茂市型花崗閃緑岩と領家带における古期花崗閃緑岩との，とくにカリ/ソーダ此 における近㭬性。

（4）乙茂型花崗閃緑岩のまわりに兒られる变成現象と領家新期変成带におけるそれと の類似一とくに複变成的な石英斑状変晶の存在。

端山好和 $\left.{ }^{5}\right)$ は角閃岩相に属する变成带を，紅柱石・珪線石・哇青石なととカリ長石と が共存する場合と共存しない場合とによつて，それでれ領家・阿武隈型および Orijärvi 型との 2 の型式に分けた。この分け方は本質的には変成带における物理条件一とくに水 蒸気压の大小に関係するもので，端山によれば前者は比較的水蒸気任が低い場合，後者は

1）岩生周一：地筫， $44 ， 879 ， 1937$.

2) 小出博：前出, 1949 .

3）有田忠雄：地筫，55, 99～104， 1949.

4) 加納博：地質， 55，137，1949.

5) 端山好和：地球科学，26２7，19２8，1956. 
第 10 図本邦の代表的な接触変成带における 鉱物組合せ (AKF図表)
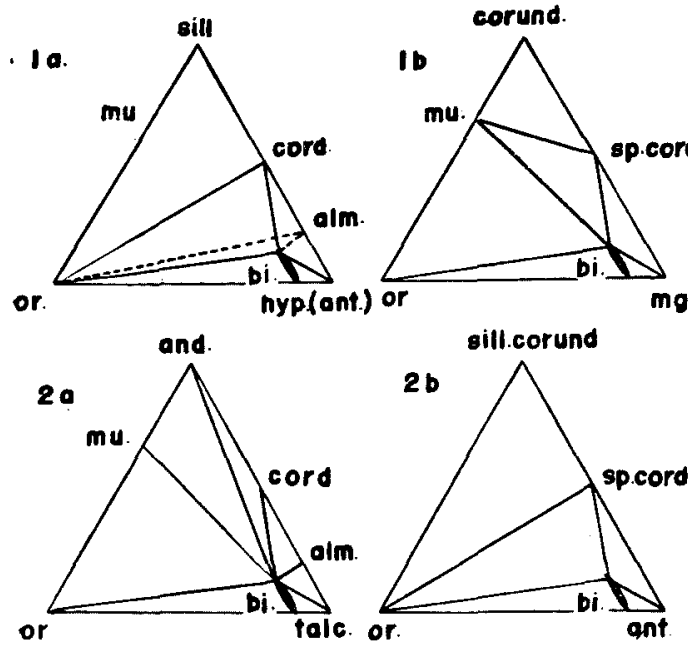

1a. 岩泉および領家古期変成带（移化带または珪線石亜带）

1b. 同 上（縞状片麻岩带または白雲母带）

2a. 遠野および千厩变成带 (紅柱石带)

2b. 同上上 (珪線石需)

sill: 珪線石, and: 紅杜石, corund:コランダム，mu：白 雲母，cord：荃青石，sp：スビネル，olm：鉄箱ざく万石，

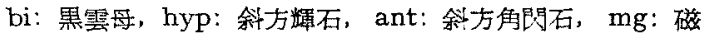
鉄鉱, or：カリ長石.

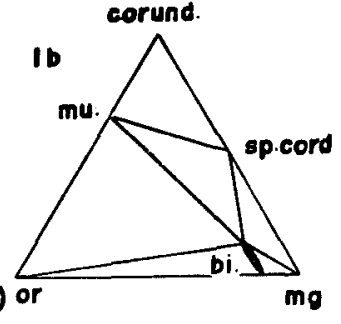

mo
水蒸気圧が比較的高い場 合と考える尌によつて種 々の鉣物悢全せがうまく 説明できるとされてい る。上に述べた特徴から， 本変成带一とくに茂市 型花崗国緑岩に関倸した 珪線石亚带にお污方鉣物 組合せが端山の領家・阿 武隈型のそれに属するこ とは明らかであり，その 铈物組合せ $\mathrm{AKF}$ 図 て示すと第 10 図(1a)の ようである。

この場合注目すべきこ とは、鏡下の钼寓から推 定されるように珪線石が 紅柱石上り安定におもわ れること，きわめて稀で あるが斜方輝石の應出が あることで,このような ことは珪線石亜魚の交成 相が角閃岩相の中でも比 較的辉石ホルンヘルス相 に近い高温部に属するこ とを暗示している。

しかし茂市型花崗閃緑岩の接螌部近くに発達する䋻状片麻岩带 (白雲母带)では鈗物組 合せの仕方は若千異なり第 10 図(1b)の上うになると考えられる。ここでは珪線石（ま たは紅杜石）とカリ長石の組合せは不安定となり，その代りにコランダム一白雲母，白雲 母一カリ是石の結合せが安定となる。しだつて変成分化作用の最終産物は一般に黑雲 母一白雲母一カり長石の安定な組合せを有する。このような組合せは，珪線石业带から自 雲乎带にかけて水蒸気压が若干高くなつたことを意味している。

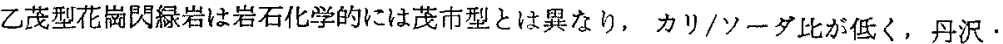
千嘅・遠野などの石英閃緑岩一トロニエム岩系に似ている。その変成带も東側（中里・田

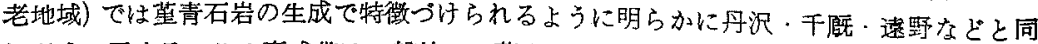
じ型式に属する。この変成带は一般的には茂市型より水蒸䒝圧が高いと考えられ，その鉝 物組合せにはおそらく第 10 図(2a) ${ }^{11}$ のような平衡関係が適用されるであるう。この揚合

1) 第 10 図 $(2 \mathrm{a}, 2 \mathrm{~b})$ は遠野抢よび千溉変成带における实際の鉣物粗合せから作成 したもので，同図ａは紅柱石带、bは珪線石带にお讨る安定関係を示す。 
には珪線石の代りに紅柱石が安定で，カリ長石は紅杜石または蕉青石とは共存しない。黒 雲母と白雲母・紅柱石・堇青石のそれぞれとを結ぶ安定結合が特徴となる。このような 安定関係は Ramberg1)によれば緑れん石角閃岩相の高温部に相当する。したがつてっ 茂型花崗閃緑岩に関する変成带は, 茂市型のそれよりはやや低温であつたと考えなければ ならない。

岩泉変成带の南東部 (小本街道以南) では茂市型变成带の珪楾石刑带または黒雲用晜が 乙茂型花崗閃緑岩に直接し，したがつて当然後者による複変成作用が期待される。しかし 䒠際には前に述へたような石英斑状変晶で示されるような珪化作用以外にはとくに複変 成現象とみられるようなものは認められない。その理由は上に述へたような茂市型変成 芇と乙茂型変成带の温度条件の差によると考えられるであらう。

以上のような変成作用の過程で，変成带の内部または変成带と花崗岩体との聞に，どの ような物䨘の移影一変成交代作用または交代作用一が行われたかはこの論文の範团外で 将来つ検討にまたなければならない。

卒業諭文作成にあたつては北大理学部地質学鉣物学教室の鈴木醇教授, 石川俊夫教授, 舟橋三男助教授に指荨していただきまた当時札帽に酫在された小出博博士からいろいる の助言をいただいた。さいきん同じ地域を研究中の島津㶧夫なる゙に国府谷盛明氏から は安家地域の変成岩について有益な知識を得た。以上の方々に愿く謝意を呈する。なお 本研究に要した費用の一部は日本学術振與会研究補助金ならびに文部省科学研究鳌交付 金に負うものである。(完)

1) Ramberg, H : Origin of Metamorphic and Metasomatic Rocks, 149, 1952.

正 誤 表 本誌 41 巻 6 号揭載の加納氏論文中, 次の通り正誤します。 260 頁上加ら 9 行目 (第 7 図) を(第 8 図)に訂正，同頁上から 10 行目(第 7 図) を(第 8 図)に訂正，262 頁上から 16〜17 行目（図版 9)を(第 9 図 1)に訂正。

\section{所請万年山熔岩の岩石化学的研究}

Petrochemistry of the so-called Haneyama lavas

$$
\text { 松，本幡 郎 (Hataro Matsumoto)* }
$$

\footnotetext{
Abstract : So-called "Haneyana-lavas", as named by T. Matsuroto, are widely distributed in central Kyushu, especially in Oita Prefecture. These lavas are mostly glassy and their texture shows various types, namely,
}

* 熊本大学理学部地学教室. 